\title{
ARTEFAK DALAM KONTEKS PERKEMBANGAN KAWASAN HERITAGE ISLAM
}

\author{
Karina Pradinie Tucunan ${ }^{1}$ \\ Utari Sulistyandari ${ }^{2}$ \\ M.Ilham Perkasa ${ }^{2}$ \\ ${ }^{1}$ Departemen Perencanaan Wilayah dan Kota Institut Teknologi Sepuluh Nopember Surabaya \\ ${ }^{2}$ Laboratorium Pengembangan dan Perancangan Kota Departemen Perencanaan Wilayah dan Kota \\ Institut Teknologi Sepuluh Nopember Surabaya \\ Penulis Korespondensi e-mail : utarindari@gmail.com
}

\begin{abstract}
Islam is the majority religion in Indonesia, but unfortunately none of the historic sites of Islam in Indonesia became a common concern in the international world. The heritage of Islamic culture is a unique heritage because there is a process of acculturation and change of civilization in a fairly fast time (50 years) from the Hindu-Buddhist kingdom to the Islamic kingdom. Islamic cultural heritage so far only focusing in the existence of mosques and tombs and not focusing in spatial management. This indicates that there is a gap of knowledge on the disciplines of archeology and spatial planning, especially in the management of cultural heritage that should be a multi-disciplinary domain. The methods used in this study is qualitative studywith focus on building a spatial and archeology approaches to the heritage management. With the aim of space categorization and also the types of artifacts available, this paper finds that artifacts are divided into two namely those found or located in the core area and those in the supporting area.
\end{abstract}

Keyword: Islamic Heritage, Artifacts

\begin{abstract}
ABSTRAK
Islam merupakan agama mayoritas di Indonesia, namun sayangnya tidak satupun situs bersejarah islam menjadi concern bersama dalam dunia Internasional. Warisan kebudayaan islam merupakan sebuah warisan yang unik karena terjadi proses akulturasi dan perubahan peradaban dala waktu yang cukup cepat (50 tahun) dari kerajaan Hindu-Budha menjadi kerajaan Islam Kawasan cagar budaya dalam pengelolaan cagar budaya kawasan islam selama ini hanya teridentifikasi pada keberadaan masjid dan makam. Hal ini mengindikasikan bahwa adanya kesenjangan pengetahuan terhadap disiplin ilmu arkeologi dan perencanaan ruang, terutama dalam pengelolaan cagar budaya yang seharusnya menjadi ranah multi disiplin ilmu. Metode yang digunakan dalam penelitian ini adalah kualitatif dengan menggunakan pengamatan tersetruktur dan konten analisis yang difokuskan pada data-data sekunder (literature review) yang menggabungkan antara ilmu arkeologi dan keruangan (spasial). Dengan tujuan dari kategorisasi ruang dan juga jenis artefak yang ada, makalah ini menemukan bahwa artefak terbagi atas dua yakni yang ditemukan atau berada di Kawasan inti dan yang berada di kawasan pendukung.
\end{abstract}

Kata Kunci:Warisan Kebudayaan Islam, Artefak 


\section{PENDAHULUAN}

Perkembangan kajian mengenai kawasan cagar budaya selalu dihdapkan pada tantangan - tantangan dalam pengelolannya. Tantangan cukup beragam dimulai dari pengelolaan finansial, pengelolaan benda langka dan lain termasuk dalam konteks perencanaan kota adalah mendeliniasikan manakah yang termasuk dalam kawasan cagar budaya. Berdasarkan UU No 11 Tahun 2010 tentang cagar budaya, yang didefinisikan dengan kawasan cagar budaya adalah sebagai berikut satuan dua geografis yang mengandung dua situs atau lebih yang letaknya berdekatan dan memiliki rekam memori mengenai kehidupan di masa lalu dari pengertian tersebut, maka dapat disimpulkan bahwa pendeliniasian kawasan cagar budaya tidak pernah terlepas dari keberadaan situs cagar budaya tersebut. Pada pengelolaan kawasan cagar budaya pada saat ini, seringkali pendeliniasian dilkukan dengan mendefinisikan secara kasar ada atau tidaknya lebih dari satu bangunan di kawasan tersebut.

Pendefinisian tersebut bertentangan dengan definisi mengenai situs cagar budaya dalam undang - undang itu sendiri yang bermakna : 1). Sebuah lokasi yang mengandung Benda Cagar Budaya, Bangunan Cagar Budaya, dan/atau Struktur Cagar Budaya dan 2). Menyimpan informasi kegiatan manusia pada masa lalu. Definisi ini harusnya menyiratkan bahwa harus tidak hanya bangunan yang perlu diperhartikan dalam perkembangan deliniasi kawasan cagar budaya, namun semua benda (artefak) yang ditemukan memiliki bobot dan peran yang sama dengan bangunan cagar budaya.

Islam merupakan agama mayoritas di Indonesia, namun sayangnya tidak satupun situs bersejarah islam menjadi concern bersama dalam dunia Internasional. Terdaftar di list UNESCO untuk arisan cagar budaya di Indonesia hanya sebagai berikut : Borobudur Temple Compounds, Komodo National Park, Prambanan Temple Compounds, Ujung Kulon National Park, Sangiran Early Man Site, Lorentz National Park, Tropical Rainforest Heritage of Sumatra, Cultural Landscape of Bali Province: the Subak System as a Manifestation of the Tri Hita Karana Philosophy (UNESCO,2017). Warisan kebudayaan islam merupakan sebuah warisan yang unik karena terjadi proses akulturasi dan perubahan peradaban dala waktu yang cukup cepat (50 tahun) dari kerajaan Hindu-Budha menjadi kerajaan Islam (Achmad, 2017). Kawasan cagar budaya dalam pengelolaan cagar budaya kawasan islam selama ini hanya teridentifikasi pada keberadaan masjid dan makam. Hal ini mengindikasikan bahwa adanya kesenjangan pengetahuan terhadap disiplin ilmu arkeologi 
dan perencanaan ruang, terutama dalam pengelolaan cagar budaya yang seharusnya menjadi ranah multi disiplin ilmu.

Rumusan masalah dalam penelitian ini adalah: Dalam pengelolaan cagar budaya islam, terutama pada hal yang bersifat penentuan aktivitas keruangan (deliniasi kawasan cagar budaya) perlu diperhatikan situs - situs cagar budaya islam yang ada, namun saat ini perhatian hanya terfokus pada Bangunan Cagar Budaya dan belum meliputi benda cagar budaya dan object intangible, sehingga pertanaan peneleitian dalam makalah ini adalah “artefak apa sajakah yang perlu diperhatikan dalam melakukan penentuan elemen ruang pada kawasan cagar budaya islam di perkotaan?” Dalam melakukan pengkajian batasan penelitian ditetapkan pada artefak yang sementara bersifat tangible saja.

\section{METODOLOGI}

Metodologi yang digunakan dalam penelitian ini adalah kualitatif dengan menggunakan pengamatan tersetruktur dan konten analisis.

\section{A. Pengamatan terstruktur (Observation)}

Pengamatan merupakan salah satu metode yang etnografi yang digunakan untuk memahami manusia, benda, pola keruangan yang didasarkan pada perspektif peneliti ataupun dalam perspetif yang lebih bersifat partisipatif. Metode ini membutuhkan pengamatan yang terkadang diawali dengan induktif ataupun kebalikannya diawali dengan sesuatu yang bersifat deduktif (terstruktur) (Baker, 2006). Pengamatan yang dipilih pada penelitian ini adalah pengamatan yang bersifat terstruktur untuk menjamin adanya duplikasi ataupun konsistensi pola yang ditemukan dalam setiap lokasi. Mengambil keumuman dari kawasan cagar budaya islam di Indonesia, peneliti memfokuskan pada 8 lokasi kawasan cagar budaya yang cukup besar yang tersebar di Jawa Tengah dan Jawa Timur, sebagaimana yang dapat dilihat pada Tabel 1 sebagai berikut.

Tabel 1. Pemilihan Sampling dan Variabel (deduktif) Yang Diamati

Sample/ Obyek Yang Diamati Variabel Yang Diamati

1. Kawasan cagar budaya Sunan Giri;

2. Kawasan cagar budaya Maulana Malik Ibrahim;

3. Kawasan cagar budaya Sunan Bonang;

4. Kawasan cagar budaya Sunan Drajad;

5. Kawasan cagar budaya Sunan Kudus;
1. Bangunan cagar budaya di kawasan tersebut;

2. Benda cagar budaya yang ditemukan di kawasan tersebut;

3. Intangible heritage $\mathrm{di}$ 

6. Kawasan cagar budaya Sunan Ampel;
kawasan tersebut.
7. Kawasan cagar budaya Sunan Mulia;
8. Kawasan cagar budaya Sunan Kudus
9. Kawasan cagar budaya Kesultanan Demak.

\section{B. Konten Analisis}

Konten analisis merupakan sebuah metode dalam ilmu komunikasi untuk menemukan sebuah insight/ penarikan kesimpulan terkait sebuah pembahasan yang valid untuk direplikasi pada penelitian selanjutnya yang kemudian didopsi untuk beragam penelitian politik dan sosial (Barelson, 1952; Holsti, 1968; Wimmer and Dominic, 1994 and Krippendorf, 1980).

Selanjutnya, Weber (1985) menetapkan set kriteria yang digunakan apakah hasil penarikan kesimpulan telah baik atau tidak dengan list sebagai berikut:

1. Objectivity: yang bermakna bahwa semakin baik temuan maka hasilnya semakin mudah untuk diduplikasi, terutama apabila bahan/ data merupakan hal yang sama;

2. Systematic: yang bermakna adanya sebuah pola/ tipologi tertentu yang bersifat sistematis yang ditemukan oleh peneliti;

3. Generalizability: yang bermakna bahwa hasil/ metode penelitian dapat digunakan pada penelitian yang lain.

Pada penelitian ini konten analisis difokuskan pada data - data sekunder (literature review) yang menggabungkan antara ilmu arkeologi dan keruangan (spasial).

\section{HASIL DAN PEMBAHASAN}

Arkeologi erat kaitannya dengan ilmu sejarah. Dilihat dari tujuannya yang sama, yaitu merekonstruksi kehidupan masa lampau dan mengungkap fakta-fakta yang ada di suatu masa hingga ke masa lainnya. Arkeologi dapat ditemukan melalui dua jenis benda yaitu benda-benda (artefak) dan bangunan (fitur) (Tjandrasasmita, 2009). Dalam konteks perwilayahan/ spasial terdapat pola yang konsisten mengenai wilayah yang dikategorikan sebagai wilayah sakral dan non sakral (Tuan, 1977). 


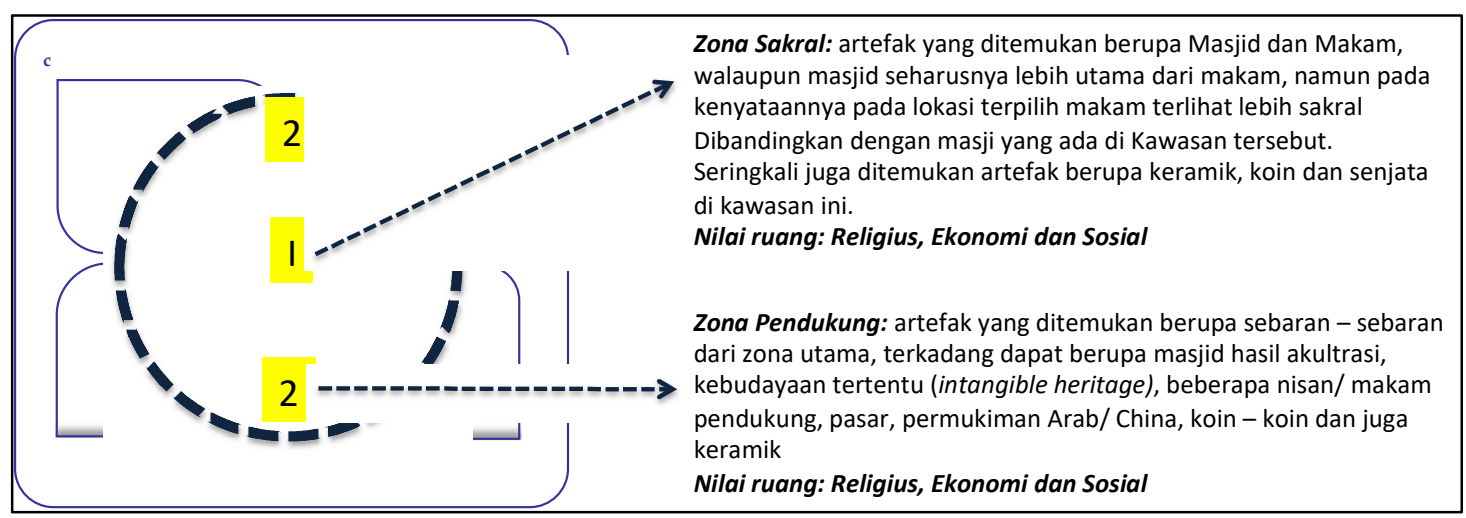

Gambar 1. Konfigurasi Spasial Ruang Sakral - Profan Islamic Urban Heritage

\section{A. Masjid}

Masjid juga merupakan jenis bangunan yang termasuk menjadi salah satu jenis dari benda arkeologi. Masjid memiliki fungsi yang krusial dalam ibadah kegiatan umat muslim, sehingga masjid selalu hadir dalam perkembangan Islam mulai dari kedatangan pertama hingga saat ini. Pada masa perkembangan Islam, masjid merupakan salah satu bukti monumental bahwa Islam diterima oleh masyarakat setempat. Dibangunnya masjid di suatu kerjaan, menandai bahwa Islam diterima secara resmi sebagai agama kerajaan (Wuri Handoko, 2013). Masjid dapat dianggap sebagai ciri utama dalam situs Kerajaan Islam, karena tradisi yang dibawa sejak masa Nabi Muhammad SAW adalah pendirikan kerajanan Islam selalu didahului dengan pembangunan masjid yang dianggap sebagai pusat kegiatan dalam segala aspek kehidupat umat. Dalam penelitian arkeologi Islam kehadiran masjid sangat menonjol karena pada umumnya posisi masjid berada di tengah-tengah sebuah kampung, bangunan masjid juga biasanya lebih tinggi daripada bangunan lainnya. Posisi ini dalam konteks arkeologi ruang dapat disimpulkan sebagai pusat orientasi dalam konsep kosmologi masyarakat Islam, karena masjid telah diposisikan sebagai simbol terhadap upaya pencarian Sang Khalik (Sang Pencipta).

\section{Masjid Menara Kudus}

Masjid Menara Kudus merupakan warisan budaya peninggal wali (Sunan Kudus) yang terletak dalam satu kompleks di Desa Kauman Kecamatan Kota Kabupaten Kudus. Sunan Kudus adalah putera Raden Usman Haji, yang menyiarkan agama islam di daerah Kudus dan sekitarnya. Sunan Kudus memiliki keahlian khusud dalam bidang ilmu agama, terutama dalam ilmu fiqih, usul fikih, tauhid, hadist, tafsir, serta logika. Dalam cerita rakyat yang berkembang Sunan Kudus pernah belajar di Baitulmakdis, Palestina, dan pernah 
berjasa memberantas penyakit yang menelan banyak korban di Palestina. Atas jasanya, Sunan Kudus dihadiahi daerah kekuasaan di Palestina namun Sunan Kudus mengharapkan daerah tersebut dipindahkan ke Pulau Jawa, dan oleh Amir (penguasa setempat) permintaan itu dikabulkan. Sekembalinya Sunan Kudus ke Jawa ia mendirikan masjid di daerah Loran tahun 1549; masjid itu diberin nama Masjid al-Aqsa atau Al-Manar (Masjid Menara Kudus) dan daerah sekitarnya diganti namanya dengan Kudus, diambil dari sebuah kota di Palestina, al-Quds (Ahfas Mutohar, 2007).

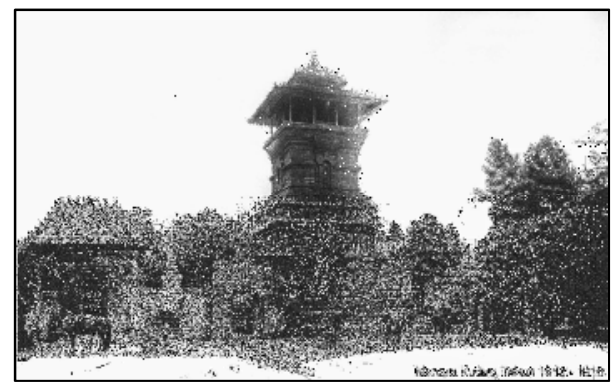

Gambar 2. Masjid Menara Kudus Sumber : menara-kudus.blogspot.com (2012)

Sunan Kudus tidak hanya berperan sebagai guru agama tetapi juga menjadi mubaligh, dan juga menjadi senopati dari kerajaan Bintoro Demak. Hal ini sesuai dengan prinsip dalam ajaran Islam, bahwa tidak ada pemisahan antara agama (religie) dan negara (staat). Hal tersebut juga dipraktekkan oleh Sunan Kudus (Solichin Salam, 1995). Dalam berdakwa, untuk menarik perhatian masyarakat Hindu-Budha dalam memeluk agama islam Sunan Kudus mengikat seekor lembu di halaman masjid Al-Aqso untuk menarik perhatian masyarakat Kudus yang masih beragama Hindu-Budha. Ketika sudah banyak masyarakat Hindu-Budha yang berkumpul maka Sunan Kudus memulai dakwahnya, hal tersebut ternyata efektif sehingga banyak dari masyarakat Hindu dan Budha memeluk agama islam. Selain itu Sunan kudus juga melarang rakyatnya menyembelih sapi karena karena kebanyakan masyarakat memilihi nenek moyang yang memeluk agama hindu dan budha. Sehingga agar tidak menyakiti dan meniyinggung perasaan dan kehormatan serta kepercayaan hidup mereka yang pada saat itu masih kuat.

Menara Kudus memang sengaja dibangun oleh Sunan Kudus menyerupai bentuk bangunan Candi. Hal ini didasarkan pada pemikiran Sunan Kudus bahwa seseorang yang telah menganut dan meyakini ajaran agama akan lebih mudah menerima ajaran dari seseorang yang menghormati dan sesuai dengan dirinya. Pemikrian ini diwujudkan oleh Sunan Kudus dengan membangun Menara Masjid yang menyerupai Candi yaitu tempat 
ibadah umat Hindu-Budha. Fungsi Menara yaitu sebagai tempat mengumandangkan adzan, meletakkan bedug, dan kentongan, serta sebagai tempat berdzikir. Area Menara Kudus dengan aktivitasnya tergolong dalam lokasi utama. Dengan demikian zoning menara yang terletak di sebelah Tenggara kompleks masjid lebih kurang $2 \mathrm{Km}$ dari alun-alun kota Kudus dan beberapa ratus meter dari pasa Kudus lama. Sehingga dapat disimpulkan zoning Menara Kudus adalah daerah utama pusat kota kompleks yang menempati wilayah aktifitas manusia (Suwoto, 2009).

\section{Masjid Ampel Surabaya}

Sunan Ampel atau yang bernama asli Raden Rahmat adalah seorang wali yang pada saat masa berdakwahnya tinggal di Ampeldenta atau Ampelgading, yang saat ini terletak di Kelurahan Ampel, Kecamatan Semampir, Kotamadya Surabaya, Provinsi Jawa Timur, Indonesia. Ayah dari Sunan Ampel bernama Maulana Malik Ibrahim atau terkenal dengan sebutan Sunan Gresik. Maulana Malik Ibrahim atau Ibrahim Asmarakandi adalah seorang keturunan Arab yang silsilahnya sampai kepada Nambi Muhammad SAW. Sedangkan ibu dari Sunan Ampel bernama Dewi Candra Wulan, seorang putri keturunan Raja Kerjaan Campa, kakak dari Dyah Dwarawati, istri Raja Majapahit Prabu Brawijaya V. Sehingga dari sisi ibu, Sunan Ampel adalah kemenakan ipar dari Raja Majapahit. Hubungan- hubungan dalam silsilah ini pada kenyataannya dalam sejarah memiliki pengaruh yang sangat besar dalam usaha dakwah Sunan Ampel menyebarkan Agama Islam di Indonesia.

Kedatangan Raden Rahmat/ Sunan Ampel atas persetujuan Raja Majapahit dalam menyebarkan Agama Islam. Pada awalnya Raja Majapahir meminta Sunan Ampel untuk mendidik moral pada bangsawan dan kawula Majapahit, yang waktu itu dilanda kekacauan dan kerusakan moral. Setelah itu banyak juga rakyat jelata yang menjadi murid di pesantren yang didirkan Sunan Ampel di Ampeldenta tersebut. Saat pertama Sunan Ampel sampai di daerah Ampel Gading Surabaya, beliau mendirikan masjid sebagai pusat dakwah dan pendidikan. Hal tersebut mencontoh sebagaimana yang dilakukan Nabi Muhammad SAW sesampainya dari Hijrah ke Madinah. Sunan Ampel mendirikan masjid sebagai pusat dakwah dan pendidikan didekat pelabuhan Surabaya, ditepi sungai Kalimas yang menghubungkan pelabuhan Surabaya dengan ibukota Majapahit lewat transportasi air sepanjang sungai Brantas. 


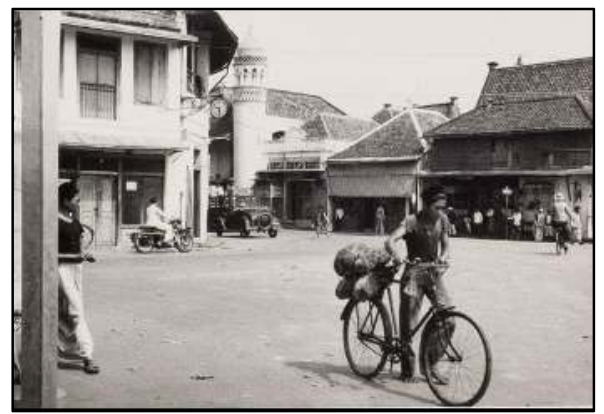

Gambar 3. Kawasan Ampel di Masa Lalu

Sumber : pesonacagarbudayasuraaya.wordpress.com (2014)

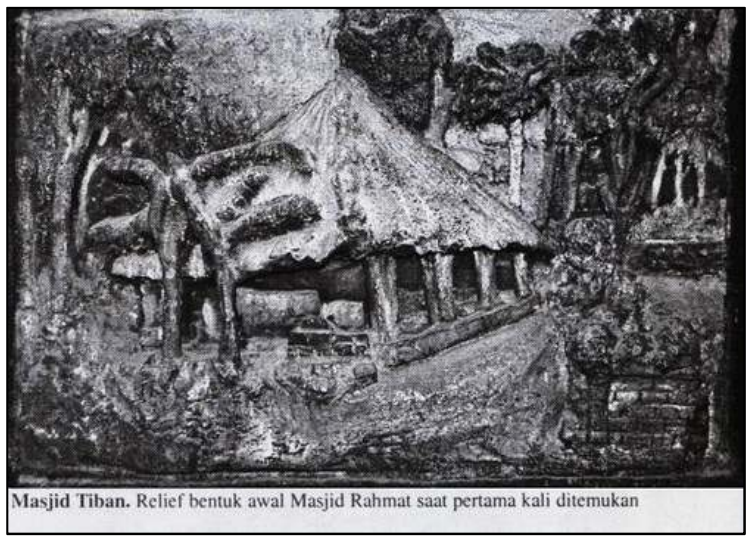

Gambar 4. Bentuk Awal Masjid Rahmat (Pendukung Kawasan Sunan Ampel) Sumber : jawatimuran.wordpress.com (2016)

Posisi tempat didirikan masjid dan pesantren tersebut sangat strategis, misalnya tempat yang sekarang menjadi pasar ikan Pabean, ditempat itu dulu ada pondok pesantren milik cucu ke- 6 dari Sunan Ampel yakni Kyai Abdullah Mansyur. Karena tempatnya yang strategis sebagai jalur perdagangan dan transportasi air laut dan sungai, pada tahun 1765 diambil alih, oleh pemerintah dan VOC. Melihat keterangan tersebut menjadi tergambar betapa dulu Sunan Ampel tidak sembarangan memilih tempat itu. Bahkan menurut Babat Gresik dalam Masykur Arif, Sejarah Lengkap Wali Sanga, tempat itu sebelumnya berair dan berlumpur namun dengan kemampuan "ilmu geologi” yang dimiliki Sunan Ampel dan sahabat-sahabatnya seperti Mbah Shonhaji yang mampu menentukan arah kiblat dengan tepat, tempat itu menjadi kering dan bisa ditempati. Posisi tersebut sangat strategis, karena menjadi pintu gerbang keluar dan masuknya orang dari dan ke Majapahit yang waktu itu adalah kerajaan terbesar di Nusantara. Dalam waktu singkat reputasi Sunan Ampel menyebar luas ke seluruh Nusantara. Banyak anak saudagar dan putra bangsawan kerajaan, berguru di pesantren Ampeldenta. Salah satu contoh santri Sunan Ampel adalah Adipati 
Arya Damar dari Palembang, seluruh keluarga kerajaan dan rakyat Palembang menyatakan diri masuk Islam. Masjid Ampel memiliki arsitektur perpaduan Jawa, Cina, dan Arab dan dibangung sekitar tahun $1421 \mathrm{M}$. Masjid dengan 16 tiang penyangga kayu jati setinggi 17 meter ini memiliki pintu-pintu sebanyak 48 buah yang diyakini terbuat dari kayu-kayu yang masih asli peninggalan Sunan Ampel.

Selain Masjid Ampel, peninggalan Sunan Ampel berupa masjid yang bisa disaksikan sampai sekarang adalah masjid Rahmat di daerah Kembang Kuning Surabaya (Gambar 3-2). Dalam perjalanan dari pusat Kerajaan Majapahit menuju ke Ampeldenta, Raden Rahmat sempat singgah beberapa hari di daerah Kembang Kuning, di sana Raden Rahmat berdakwah dan sempat mendirikan langgar sebagai tempat ibadah. Langgar tersebut kemudian dipugar menjadi masjid besar bernama Masjir Rahmat. Banyak kalangan yang menafsirkan bahwa Raden Rahman meneladani Nabi Muhammad saat hijrah sebelum memasuki Madinah sempat singgah di suatu tempat dan mendirikan rumah ibadah yang dikenal dengan Masjid Quba.

Melihat dari sisi peninggalan intangible, berupa filosofi dan sejarah yang dimiliki oleh Masjid yang merupakan bentuk peninggalan tangible dari perkembangan Islam maka seharusnya area masjid dan sekitarnya dapat dikatakan sebagai Kawasan Bersejarah. Karena nilai-nilai serta perkembangan yang terjadi disekitar masjid membuktikan bahwa keberadaan masjid merupakan hal yang essensial dalam penyebaran agama Islam oleh Sunan Ampel dan Sunan Kudus. Masjid menjadi tempat berdakwah, sosialisasi, serta terbuka bagi semua orang untuk mengenal Islam pada saat itu. Posisi masjid juga selalu di tempat strategis dimana kegiatan masyarakat ramai terjadi sehingga mempengaruhi keruangan dalam kota Kudus dan kota Surabaya pada zaman tersebut.

\section{B. Makam}

Makam merupakan salah satu artefak yang penting dalam tinjauan spasial. Hal ini disebabkan adanya aktifitas manusia pada makam- makam yang disakralkan dan kemudian mempengaruhi bentuk ruang perkotaan. Makam yang memiliki artefak berupa batu nisan. Batu nisan dapat menjadi bukti adanya perdagangan pada masa lampau: jika kita melihat bentuk, jenis batu, dekorasi, dan gaya huruf yang dimiliki batu nisan tersebut. Dalam hal urban archaeology, artefak berupa batu nisan menjadi penting sebagai bukti adanya peradaban di daerah tersebut. Contohnya penemuan makam Malik Ibrahim yang bertuliskan tanggal 822 H (1419 M) di Gresik dan penemuan makam di Troloyo, Trowulan, Jawa Timur yang bertanggal 1379 çaka (1457 M) (L.-Ch. Damais, 1957; Bernet Kempers, 
1959) yang menunjukkan terdapat masyarakat Muslim yang tinggal di dekat ibukota Majapahit dan sekitarnya saat kerajaan itu masih berkuasa (Tjandrasasmita, 2009). Selain itu, JP Moquette telah menganalisis makam Malik Ibrahim di Gresik ternyata memiliki kemiripan batu nisan dari segi jenis \& sistem penulisan dan jenis batu dengan makam di Samudera Pasai bertahun $822 \mathrm{H}$ dan $831 \mathrm{H}$, juga batu nisan Umar bin Al Kazurani dari Cambay $754 \mathrm{H}$ sehingga diduga adalah produk yang sama dari Cambay (J.P. Moquette, 1912: 536-553; 1920: 44-47). Dapat disimpulkan, batu nisan yang mirip di tiga wilayah ini menggambarkan terjadinya perdagangan antara Gujarat, Samudera Pasai, dan pantai utara Jawa Timur, yang pada masa itu sudah ramai (Tjandrasasmita, 2009).

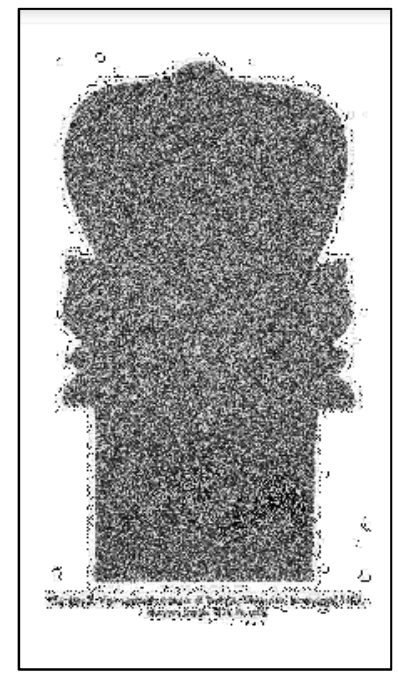

Gambar 5. Nisan Sebuah makan di Troloyo, Trowulan 1427 Sumber : Tjandrasasmita, 2009

Batu nisan merupakan tinggalan budaya terkait dengan sistem penguburan yang banyak ditemukan pada situs-situs arkeologi dari masa pengaruh Islam (Inagurasi, 2017). Makam Sultan Samudera Pasai ke-2, Sultan Malik az-Zahir, memiliki batu nisan yang berinkripsi. Tulisannya adalah, "Kubur ini kepunyaan yang mulia Sulan Malik az-Zahir, cahaya dunia dan sinar agama Muhammad bin Malik al Shalih, yang wafat pada malam Ahad, dua belas bulan Zhulhujjah tahun 726" (Bathuthah, 2012). Kita sangat beruntung dengan adanya inkripsi di makam raja-raja Pasai, dari tulisan yang tertera itu bisa diketahui berapa lama agama Islam telah masuk ke Nusantara. Selain inkripsi, terdapat ragam hias pada nisan yang dapat menggambarkan latar belakang budaya dan masanya. Misalkan nisan tipe Aceh yang tampaknya ragam hiasnya dipengaruhi oleh pengetahuan ragam hias sebelum kehadiran Islam, terdapat budaya peralihan dari sebelum Islam datang dan 
setelahnya. Ragam hias pada masa peralihan umumnya merepresentasikan bentuk makhluk hidup yang samar (Inagurasi, 2017).

\section{Koin/ Mata Uang}

Koin atau mata uang dapat menjadi bukti otentik keberadaan peradaban Islam masa lalu. Mata uang dapat menggambarkan masa sultan yang saat itu berkuasa, urutan sultan yang berkuasa, keterkaitan dan pengaruh antarkerajaan, dan masa kejayaan kerajaan, sedangkan pola inkripsi yang terdapat di kedua sisi mata uang dapat mengetahui gelar atau ungkapan dari nama-nama sultan serta pola jenis-jenis khat (Lestari, 2014). Sebagai contoh, mata uang yang diterbitkan oleh Kesultanan Aceh Darussalam yang masih dipengaruhi oleh Kesultanan Samudera Pasai, ditandai dengan adanya inkripsi "as-Sultan al-Adil" di masa kepemimpinan Sultan Alau ad-Din (1577 - 1586 M) dan Sultan Ali ad-Din (1589 - 1604 M). Sejak masa kepemimpinan selanjutnya, Sultan Iskandar Muda (1607 - 1636 M), sudah tidak lagi terpengaruh oleh Kesultanan Samudera Pasai karena di mata uang tidak lagi ada inkripsi “as-Sultan al-Adil”, tetapi tulisan nama-nama sultan yang menerbitkan mata uang dan juga nama yang menunjukkan silsilah. Selanjutnya, ukuran mata uang yang dikeluarkan Sultan Iskandar Muda di Kesultanan Aceh Darussalam dan Sultan Zainal di Kesultanan Samudera Pasai lebih besar daripada mata uang di masa sultan sebelum mereka, hal ini menunjukkan terjadinya masa kejayaan saat masa kepemimpinan kedua sultan di masing-masing kesultanan (Lestari, 2014).

Dalam konteks spasial penemuan koin dapat digunakan sebagai ukuran deliniatif yang bersifat imajiner yang dapat menggambarkan wilayah deliniasi yang lebih luas, apabila dibandingkan dengan obyek utama yang ada di kawasan sakral saja. Penemuan koin dapat memperbesar area pendukung jika dapat ditemukan koin tersebut dapat ditemukan di sebuah lokasi tertentu.

\section{Keramik/ Batu/ Ukiran Kaligrafi Islam}

Keramik/ batu maupun ukiran menjadi bagian yang penting bagi keilmuan sejarah, bukan hanya dari segi arkeologi, karena dapat memberikan suatu rekonstruksi sejarah perdagangan antara Indonesia dan Tiongkok, maupun juga Indonesia dengan negara di Timur Tengah (kasus Masjid Kudus) dan negara - negara seperti Gujarat dan India (Tjandrasamita, 2009). Berikut ini merupakan contoh dari kaitan antara artefak beserta intangible heritage yang menyertainya. 


\section{Kesultanan Cirebon}

Cirebon mulai dikenal pada pertengahan abad ke-15 sebagai pusat keagamaan, politik dan ekonomi. Lalu pada masa kekuasaan Sunan Gunung Jati pada akhir abad ke-15 Cirebon menjadi pusat penyebaran agama Islam di pantai utara Jawa. Cirebon menjadi tempat penting dalam jalur pelayaran dan perdagangan antar bangsa, membuatnya menjadi jembatan budaya antar negara yang singgah, sehingga banyak peninggalan-peninggalan purbakala, kesenian, dan warisan non fisik yang menjadi bukti tentang masuknya aneka ragam budaya dari berbagai penjuru dunia. Negara-negara tersebut antara lain adalah Arab, India, Cina, dan Eropa. Beberapa bukti hubungan itu, tampak berbagai jenis keramik Cina dan Belanda menghias tembok-tembok keraton, makam, dan masjid (Harkatingisih, 2004).
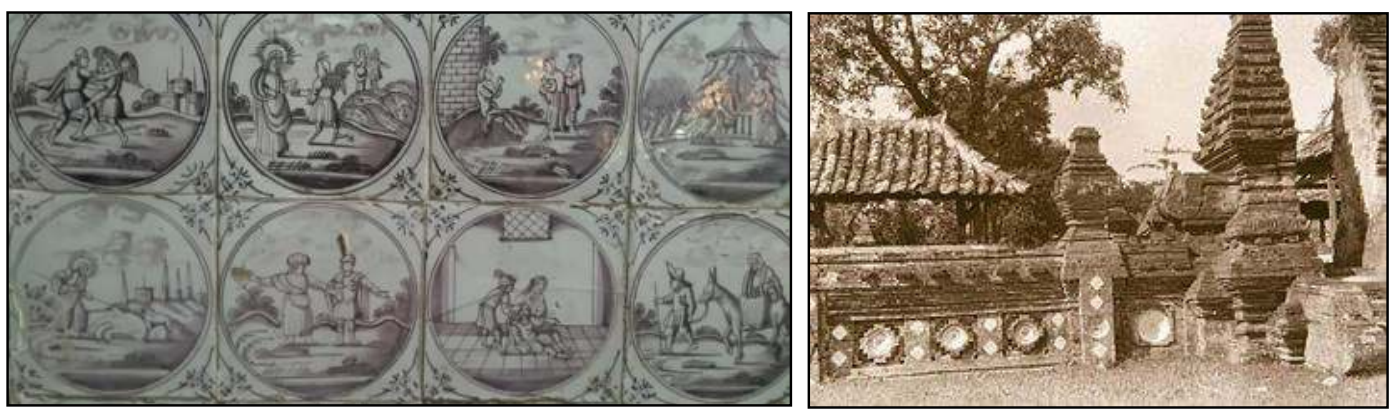

Gambar 4. Keramik Peninggalan Kesultanan Cirebon Sumber : filckr.com (2009)

Dampak dari singgahnya banyak negara dan Cirebon sebagai jalur perdagangan yang penting maka Cirebon sebagai kerajaan Islam tidak hanya tumbuh dalam lingkup agama dan birokrasi, namun juga berkembang sebagai kota tempat dibangunnya berbagai infrastruktur untuk menunjang perannya sebagai jalur pelayaran dan perdagangan antar bangsa. Kondisi ini akhirnya lebih memperkuat adanya kebinekaan bangsa dan etnis pad masa itu. Masuknya keanekargaman budaya yang saling mempengaruhi berdampak ada pencampuran budaya, hal tersebut tampat di berbagai peninggalan arkeologi, antara lain arsitektur bangunan, motif hias gunungan, kesenian dan warisan non fisik.

\section{Kesultanan Banten}

Setelah berhasil menaklukan kerajaan Banten Girang yang bercorak Hindu Syarif Hidayatullah atau Sunan Gunung Jati memberikan nasihat kepada anaknya, Maulana Hasanuddin untuk memindahkan ibukota kerajaan di Banten Girang ke Banten lama. 
Setelah itu kesultanan Banten berkembang pesat sebagai kota bandar terkemuka dengan hasil bumi utama berupa lada (Hadiwibowo, 2013).
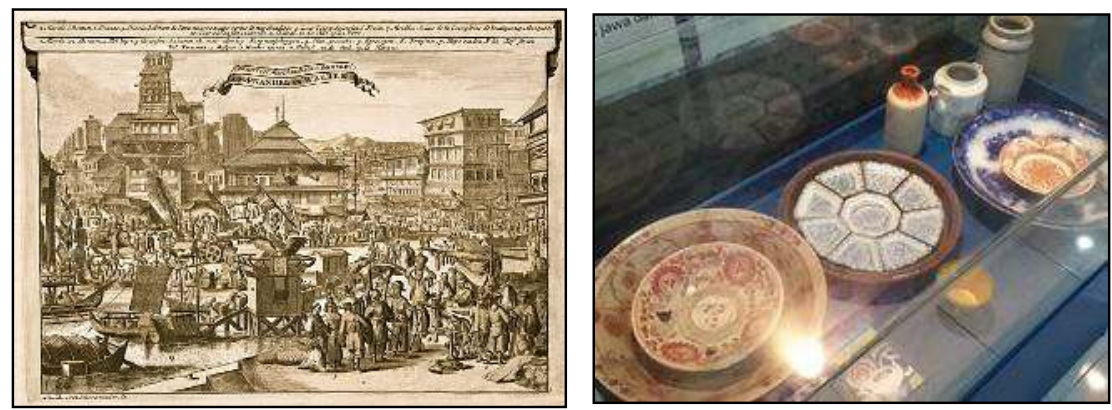

Gambar 5. Keramik Peninggalan Kesultanan Banten Sumber : sebandung.com (2015)

Dalam situs kepurbakalaan Banten Lama ditemukan benda-benda peninggalan penting pada masa kesultanan Banten, salah satunya berupa keramik. Hal tersebut membuktikan bahwa kesultanan yang terletak pada daerah pesisir pantai menjadi tempat strategis bagi terciptanya hubungan dengan dunia internasional. Perdagangan-perdagangan yang dilakukan di sekitar pelabuhan utama, memunculkan kebudayaan pesisir yang heterogen. Lewat daerah pesisir, Kesultanan Banten berkembang dan memegang peranan penting dalam proses penyebaran agama Islam ke wilayah pedalaman.

Keramik merupakan salah satu bentuk peninggalan tangible pada saat berkembangnya kerajaan Islam yang berada pada daerah pesisir. Keramik menjadi suatu bukti akan keragaman budaya yang kemudian diadopsi menjadi penghias rumah-rumah ibadah sebagai suatu bentuk persahabatan bagi kedua negara. Banyak situs-situs peninggalan di Cirebon dan Banten yang dihiasi oleh keramik, seharusnya hal tersebut telah cukup memberikan gambaran bahwa pada kawasan disekiar situs merupakan kawasan bersejarah tempat berkembangnya kegatan perdagangan dahulu.

\section{KESIMPULAN DAN SARAN}

\section{A. Kesimpulan}

Pendekatan spasial perlu arkeologi untuk membangun sejarah dan menentukan nilai keruangan, dalam Islamic Heritage yang signifikan adalah Zona Sakral dan Zona Pendukung. Sehingga apabila suatu artefak tangible ditemukan, untuk menentukan nilai keruangannya maka perlu dinilai terlebih dahulu zona sakral dan zona pendukung artefak tersebut. Sehingga pengelolaan cagar budaya islam dapat terintegrasi dengan penataan kota. 


\section{B. Saran}

Perlunya fokus pada kontemplasi dan refleksi pada nilai-nilai arkeologi untuk menentukan nilai dan penataan ruang heritage di masa mendatang menjadi hal yang perlu diperhatikan. Agar artefak tidak hanya dilihat sebagai benda namun juga dapat menjadi unsur spasial dan menghindari hilangnya identitas sejarah suatu ruang dan putusnya ikatan masa lalu dengan masa mendatang.

\section{DAFTAR PUSTAKA}

Achmad, Sri Wintala. (2017). Sejarah Islam di Tanah Jawa; Mulai dari Masuk Hingga Perkembangannya. Yogyakarta : Araska.

Ahfas Muntohar. (2007). Inventarisasi Benda Cagar Budaya (BCG). Kudus : Pemkab Kudus

Anonim. (2010). Undang Undang No.11 Tahun 2010 Tentang Cagar Budaya. Pemerintah Republik Indonesia.

Baker, L M (2006). Observation: A Complex Research Method. Library Trends. 55 (1) 171-189.

Bathuthah, M. B. (2012). Rihlah Ibnu Batutah: Memoar Perjalanan Keliling Dunia di Abad Pertengahan. Jakarta :Pustaka Al-Kautsar.

Berelson, B. (1952). Content Analysis in Communication Research, New York: The Free Press

Hadiwibowo, Tubagus Umar Syarif. (2013). Perkembangan Kesultanan Banten pada Masa Pemerintahan Sultan Maulana Yusuf (1570-1580). Skripsi. Yogyakarta :Universitas Negeri Yogyakarta.

Handoko, W. (2013). Arsitektur Masjid Kuno dan Perkembangan Islam di Maluku. Jurnal Penelitian dan Pengembangan Arkeologi: Jakarta: Pusat Penelitian Arkeologi Nasional.

Harkatingisih, Naniek. (2017). Seni Hias Tempel Keramik Kesultanan Cirebon: Toleransi dalam Kebinekaan. Kapata Arkeologi, 13(2), 233-246.

Holsti, O.R. (1968). Content Analysis. In G.Lindzey \& E.Aronson (Eds.), The Handbook of Social Psychology (2nd ed.) (Pp.596-692). New Delhi: Amerind Publishing Co

Inagurasi, L. H. (2017, May). Ragam Hias Batu Nisan Tipe Aceh pada Makam-Makam Kuno di Indonesia Abad ke 13-17. Kalpataru Majalah Arkeologi. 26 (1), 37-52.

Masykur, Arif. (2013). Sejarah Lengkap Wali Sanga. Yogyakarta : Dipta. 
Krippendorff, K. (1980). Content Analysis: An Introduction to its Methodology. London: Sage

Lestari, N. (2014). Mata Uang Emas Kesultanan Aceh dan Samudera Pasai, Kajian Numismatik dan Arkeologis.Skripsi. Depok: Universitas Indonesia.

Tjandrasasmita, U. (2009). Arkeologi Islam Nusantara. Jakarta : Kepustakaan Populer Gramedia (KPG).

Tuan, Yi-Fu (1977). Space and Place: The Perspective of Experience. Minneapolis: University of Minnesota Press

Salam, Solichin (1995). Kudus selayang pandang. Kudus : Gema Salam.

Suwoto. (2009). Folklor Menara, Masjid, Dan Makam Sunan Kudus Sebagai Pengayaan Materi Pembelajaran Sejarah (Studi Kasus Di Madrasah Aliyah Nahdlatul Ulama Banat Kudus). Thesis. Solo : Universitas Sebelas Maret.

UNESCO (2017). List of World Heritage. Retrieve from http://whc.unesco.org/en/list/ . Pada Tanggal 4 Juli 2018 Pukul

Wimmer, R.D., \& Dominick, J.R. (1994) Mass Media Research: An Introduction (4th ed), California: Wadsworth

Weber. R.P. (1985). Basic Content Analysis, New Delhi: Sage 